Diabetologia 11, 181-186(1975)

(c) by Springer-Verlag 1975

\title{
Effect of Hypophysectomy on Protein Synthetic-Activity of Free and Bound Hepatic Ribosomes from Insulin-Deficient Rats
}

\author{
F. P. Alford, P. S. Cook and G. M. Reaven \\ Dept. of Medicine, Stanford University School of Medicine and Veterans Administration Hospital, Palo Alto, California, \\ U.S.A. \\ Received: October 1, 1974, and in revised form: February 13, 1975
}

\begin{abstract}
Summary. Acute insulin deficiency in rats results in a decrease in the in vitro protein synthetic activity of isolated hepatic membrane-bound ribosomes and an increase in activity of free ribosomes. These changes are prevented by concomitant insulin treatment and are reversed by the administration of insulin. The current study evaluated the role of the pituitary in the genesis of these changes. The severity of diabetes produced by streptozotocin was less in hypophysectomized ( $\mathrm{Hx})$ rats, and in $\mathrm{Hx}$ rats receiving hormone replacement, as compared with similarly streptozotocin-treated intact rats. Although acute insulin deficiency in intact rats produced the previously described increase in protein syn-
\end{abstract}

thetic activity of free hepatic ribosomes and decrease in activity of hepatic bound ribosomes, these changes did not occur in $\mathrm{Hx}$ rats, even when $\mathrm{Hx}$ rats received replacement doses of thyroxine, ACTH, and growth hormone. Thus, the changes in hepatic protein synthetic activity that occur in rats with acute experimental diabetes mellitus are secondary to the metabolic sequelae of insulin lack and the response of the pituitary gland to insulin deficiency.

Key words: Streptozotocin diabetes, hypophysectomy, rats, hormonal replacement, free and bound ribosomes, protein synthesis.
Previous studies from our laboratory have demonstrated that in vitro hepatic protein synthesis was decreased in rats with acute and severe diabetes mellitus $[1,2]$, and that this decrease in protein synthesis was accompanied by a marked loss and disruption of the hepatic rough endoplasmic reticulum [2]. Later studies revealed that the number of ribosomes bound to the remaining fragmented rough endoplasmic reticulum was also significantly reduced per unit area of rough endoplasmic reticulum [3], and that the decrease in total hepatic protein synthesis was restricted to the bound polyribosome population [3]. In contrast, hepatic ribosomes, lying free in the cytoplasm, were not reduced in number, and these free polyribosomes were more active than normal in carrying out in vitro protein synthesis [3]. Because these changes in structure and function of free and membrane-bound ribosomes were found to be similar regardless of the method used to produce the diabetes and were prevented by the concomitant administration of insulin [3], it was assumed that the changes represented a specific response to either insulin deficiency or its metabolic sequelae. Furthermore, in the case of the bound polyribosomes, the marked disruption and loss of the rough endoplasmic reticulum and its associated bound ribosomes that occurred in diabetes seemed to offer an explanation for the decrease in protein synthetic activity of this popula-

\footnotetext{
* Supported in part by funds from the Veterans Admin istration, from N.H.L.T. Research Grant HL 08506, N.I.H., and from the Evelyn L. Neizer Fund.
}

tion of hepatic ribosomes $[2,3]$. On the other hand, neither the cause nor the significance of the observed increase in hepatic protein synthesis of the free ribosomes was apparent. Accelerated gluconeogenesis occurs in acute diabetes, so we suggested that the increased protein synthetic activity of free hepatic ribosomes was related to the demand for increased synthesis of gluconeogenic enzymes. The importance of pituitary hormone secretion in the metabolic response to insulin deficiency has been apparent since the classic studies of Houssay [4], and more recently hormones of the pituitary-adrenal axis have been shown to modify the levels of hepatic gluconeogenic enzymes [5]. Therefore, in the present study we have examined the effect of pituitary ablation on hepatic protein synthesis by membrane-bound and free ribosomes in insulin-deficient rats.

\section{Materials and Methods \\ Experimental Protocol}

Female Sprague Dawley rats (Horton Laboratory, Berkeley, Cal.) weighing $140-150 \mathrm{~g}$ were used for all experiments. Hx rats were received on the third postoperative day. Non-operated, age matched rats from the same source were used as controls (Intact).

\section{Abbreviations Used in this Paper}

Hx, hypophysectomized; $T_{4}$, thyroxine; ACTH, adrenocorticotrophic hormone; GH, growth hormone; mRNA, messenger RNA; TKM-S, $0.05 \mathrm{M}$ Tris- $\mathrm{HCl}, 0.025 \mathrm{M} \mathrm{KCl}$, $0.004 \mathrm{M} \mathrm{MgCl}, 0.025 \mathrm{M}$ ultrapure, ribonuclease free, sucrose. 
Animals were housed in pairs and given Berkeley Standard Rat Diet (Foodstuffs Processing Co., Cal.) and water ad libitum. Rats were weighed regularly and daily food intake recorded. Room lighting was controlled on a $12 \mathrm{hr}$ dark: $12 \mathrm{hr}$ light regime, and rats were maintained in this fashion for the duration of experiments. Completeness of hypophysectomy was indicated by failure of rats to gain weight over the two weeks of observation, $\mathrm{Hx}$ rats losing $1.0-1.5 \mathrm{~g}$ per day over this period [6].

Four groups of rats were studied; Intact; $\mathrm{Hx}$ rats without any replacement; $\mathrm{Hx}$ rats treated with replacement doses $[7,8,9]$ of $\mathrm{T}_{4}(4 \mu \mathrm{g} \mathrm{SC}$ daily in normal saline) and ACTH gel ${ }^{1}$ ( 2 units SC daily); and $\mathrm{Hx}$ rats treated with the above amounts of $\mathrm{T}_{4}, \mathrm{ACTH}$, and replacement doses $(6,9)$ of bovine $\mathrm{GH}^{2}(100 \mu \mathrm{g}$ $\mathrm{SC}$ per day in normal saline, $\mathrm{pH} 9.0$ ). Hormone replacement was commenced on the 14th postoperative day, all injections being given at 4 p.m. and continued daily until the time of sacrifice. On the $\mathrm{ACTH} / \mathrm{T}_{4} / \mathrm{GH}$ regime, rats gained $2.5 \pm 0.2$ (SE) g/day $[6,9]$ as compared to a gain in intact control rats of $2.2 \pm 0.1$ $\mathrm{g} /$ day. Details of body weight changes of the four groups of rats are given in Table 1.

Within all four experimental groups, rats with animals with a similar "degree of severity" 4 of diabetes were selected for study.

\section{Isolation of Free and Membrane-Bound Ribosomes}

Free and membrane-bound polyribosomes were prepared from the $500 \mathrm{~g}$ (average) supernate fraction of a liver homogenate by a discontinuous sucrose gradient technique $[10,11]$ in the presence of ribonuclease inhibitor [12], as previously detailed from this laboratory [3], but with a minor modification for the preparation of the bound pellet. After addition of sodium deoxycholate (final concentration $1.2 \%$ ) to the bound ribosome fraction, it was subjected to a further centrifugation for six hours at $105,000 \mathrm{~g}$ through $3 \mathrm{ml}$ of $1.5 \mathrm{M}$ sucrose containing the ribonuclease inhibitor. The upper layer was discarded, the lower $1.5 \mathrm{M}$ sucrose layer and bound pellet were diluted with $\mathrm{pH} 7.6$ - TKM S 0.25 and centrifuged for a final four hours at $105,000 \mathrm{~g}$. The isolated free and bound ribosome pellets were suspended in $\mathrm{pH} 7.6-$ TKM S 0.25 , aliquoted and stored at $-20^{\circ} \mathrm{C}$ until assay. Recoveries of free and bound ribosomes, measured as ribosomal RNA and expressed as mg ribosomal RNA/g wet weight liver, were similar to those published previously from this laboratory [3].

Table 1. Mean $\pm S E M$ body weights $(\mathrm{g})$ of control and diabetic (non-hormone, $T_{4} / A C T H I$ and $T_{4} / A C T H / G H$ treated) rats, immediately prior to and following streptozotocin $(100 \mathrm{mg} / \mathrm{kg})$ injection

\begin{tabular}{llllll}
\hline \multirow{2}{*}{ Controls } & \multicolumn{2}{l}{ Hyposectomised } & Intact \\
\cline { 2 - 5 } & & \multicolumn{1}{c}{$\mathrm{T}_{4} / \mathrm{ACTH}$} & $\mathrm{T}_{4} / \mathrm{ACTH} / \mathrm{GH}$ & \\
\hline \multirow{3}{*}{ Diabetic } & Day 0 & $138 \pm 3$ & $131 \pm 2$ & $145 \pm 2$ & $190 \pm 4$ \\
& Day 3 & $134 \pm 4$ & $129 \pm 2$ & $140 \pm 3$ & $193 \pm 4$ \\
& Day 0 & $133 \pm 3$ & $127 \pm 3$ & $144 \pm 2$ & $191 \pm 6$ \\
& Day 3 & $118 \pm 1$ & $109 \pm 3$ & $113 \pm 2$ & $155 \pm 5$ \\
\hline
\end{tabular}

streptozotocin-induced diabetes were compared with their respective non-diabetic controls. Diabetes mellitus was induced on the 20 th postoperative day by an intravenous injection of streptozotocin ${ }^{3}(100 \mathrm{mg} / \mathrm{kg}$ in $\mathrm{pH} 4.2$ citrate-saline buffer) after a $12 \mathrm{hr}$ overnight fast. Control rats were injected with an equal volume of buffer solution. Animals were allowed to eat and drink ad libitum and were killed by decapitation after an overnight $12 \mathrm{hr}$ fast, three days after the streptozotocin administration. Because the injection technique was not always perfect, at the time of death only

1 ACTHAR gel, obtained from Armour Pharmaceuticals, Los Angeles, California.

2 Gift of the National Institute of Arthritis and Metabolic Disease, Pituitary Hormone Distribution Program, Lot NIHGH-317, 0.92 IU/mg.

3 Streptozotocin was a gift of the Upjohn Company, Kalamazoo. Michigan by courtesy of Dr. W. D. Dulin.

\section{Incubation of Ribosomes}

In vitro protein synthetic activity of isolated ribosomes was estimated from the rate of incorporation of ${ }^{3} \mathrm{H}$-phenylalanine $(20 \mathrm{Ci} / \mathrm{mmole}, \mathrm{New}$ England Nuclear Corp.) into precipitable radioactivity $[1,3]$. The rate of incorporation of labelled amino acid into protein is directly proportional to the amount of ribosomal RNA used and the amount of ribosomal RNA is the rate limiting factor for protein synthesis. Details of the assay system have been published elsewhere [1, 3]. In brief, protein synthetic activity was estimated in a $275 \mu \mathrm{l}$ volume incubation mixture, containing ribosomes $(20-30 \mu \mathrm{g}$ ribosomal RNA),

4 Selection was based upon the presence of similar blood glucose levels, comparable weight loss, and quantitatively similar daily food intakes. This resulted in the rejection of approximately $25 \%$ of "diabetic" rats. 
19 amino acids $(0.04 \mu \mathrm{mol}),{ }^{3} \mathrm{H}$-phenylalanine, GTP $(0.10 \mu \mathrm{mol})$, ATP, $(0.5 \mu \mathrm{mol})$, phosphoenolpyruvate $(2.0 \mu \mathrm{mol})$, pyruvate kinase $(9 \mu \mathrm{g})$, dithio threitol $(0.2 \mu \mathrm{mol})$, Tris-HCl buffer $\mathrm{pH} 7.8$, and a Sephadex G-25 liver cell cytosol $(150 \mu$ g protein $/ 25$ $\mu \mathrm{g}$ ribosomal RNA) [13] and $\mathrm{pH} 5$ fraction preparations from normal rat liver $(250 \mu \mathrm{g}$ protein $/ 25 \mu \mathrm{g}$ ribosomal RNA) [14]. Cell cytosol enzyme preparations were used at saturable concentrations $[1,3]$, and optimum activity of the assay was at $7.0 \mathrm{mM} \mathrm{Mg}$. Relative differences in amino acid incorporation for the various ribosome populations persisted at $\mathrm{Mg}$ concentrations between 3-18 mM. Protein synthetic activity was expressed as cpm of ${ }^{3} \mathrm{H}$-phenylalanine incorporated into protein per milligram ribosomal RNA. Comparisons between the protein synthetic activity of ribosomes from the four experimental groups were made with samples prepared on the same day and incubated in the same assay.

\section{Analytical Procedures}

Blood glucose was measured from glucose oxidase impregnated paper strips by a Reflectance Meter [15]. Ribosomal RNA was estimated by the procedure of Fleck and Monro [16] and protein content of cell cytosol enzyme preparations by the method of Lowry [17]. Differences between experimental groups were assessed by Student'st-test [18].

\section{Results}

\section{General Observations}

Following the administration of streptozotocin, definite diabetes developed in all $\mathrm{Hx}$ and Intact rats, but, despite the fact that identical doses of streptozotocin were used, the effects and severity of the insulin-deficiency were not uniform for each experimental group of rats (Fig. 1). Thus, blood glucose levels were lowest for untreated $\mathrm{Hx}$ rats, and rose in a stepwise fashion through $\mathrm{Hx}$ rats maintained on $\mathrm{ACTH} / \mathrm{T}_{4}$ and $\mathrm{ACTH} / \mathrm{T}_{4} / \mathrm{GH}$ respectively. However, full hormonal replacement did not result in the degree of hyperglycemia seen in intact diabetic rats. Similarly, weight loss and daily food intake were least for $\mathrm{Hx}$ rats not treated with replacement hormones, rose with hormone replacement, and were greatest for Intact diabetic rats (Fig. 1). The pattern of the blood glucose levels and food intakes for the various control $\mathrm{Hx}$ and Intact groups mirrored those observed for their respective diabetic $\mathrm{Hx}$ and Intact groups, except that values were in the normal range [3]. Body weights of control $\mathrm{Hx}$ and Intact rats did not change signifcantly over the three day experimental period.

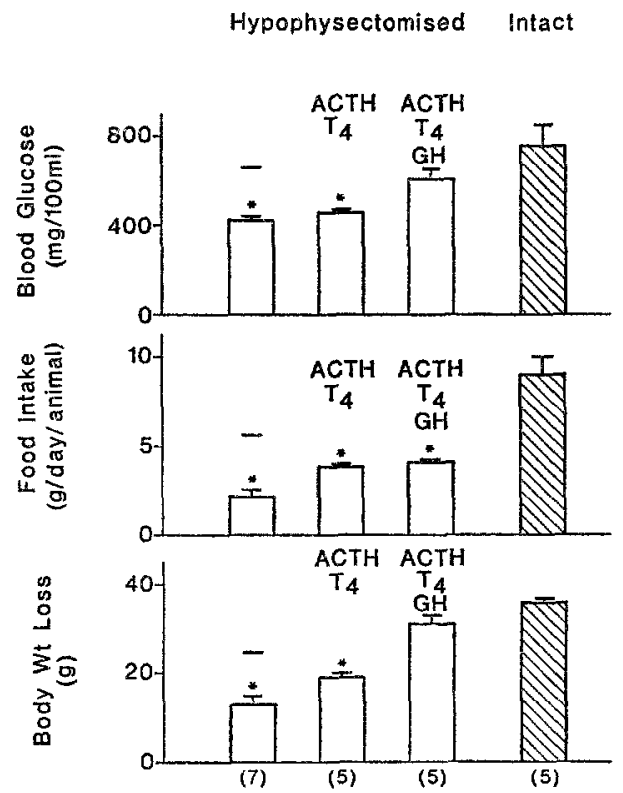

Fig. 1. Mean $\pm S E$ changes in blood glucose concentrations, daily food intakes and body weights of diabetic $\mathrm{Hx}$ (nonhormone, ACTH $/ \mathrm{T}_{4}$ and $\mathrm{ACTH} / \mathrm{T}_{4} / \mathrm{GH}$ treated) and diabetic Intact rats following the administration of streptozotocin $(100 \mathrm{mg} / \mathrm{kg})$. The numbers in parenthesis indicate the number of animals in each experimental group. The p statistic, $<0.01$ denoted by *, refers to the comparison between the Intact diabetic and each Hx diabetic group

\section{Effect of Insulin-Deficiency on Protein Synthesis by Free Hepatic Ribosomes}

The effects of acute streptozotocin diabetes on in vitro protein synthesis by isolated free ribosomes from Intact rats and from the three groups of $\mathrm{Hx}$ rats are shown in Table 2 and Fig. 2. Results in Fig. 2 are expressed as the ratio of protein-synthetic activity of diabetic to control free ribosomes. The protein-synthetic activity of free hepatic polyribosomes isolated from Intact diabetic rats was, as previously described [3], significantly increased. On the other hand, acute diabetes had no apparent effect on in vitro protein synthesis by isolated free hepatic polyribosomes from Hx rats, and hormonal replacement did not result in a return to the increased protein synthetic activity characteristic of the Intact diabetic rat.

\section{Effect of Insulin-Deficiency on Protein Synthesis by Bound Hepatic Ribosomes}

The effects of acute streptozotocin diabetes on in vitro protein synthesis by isolated bound hepatic polyribosomes from each experimental group are shown in Table 2, and in Fig. 3 are again expressed as a ratio of protein synthetic activity of diabetic to normal ribosomes. As found previously [3], acute insulindeficiency resulted in a decrease of in vitro protein 


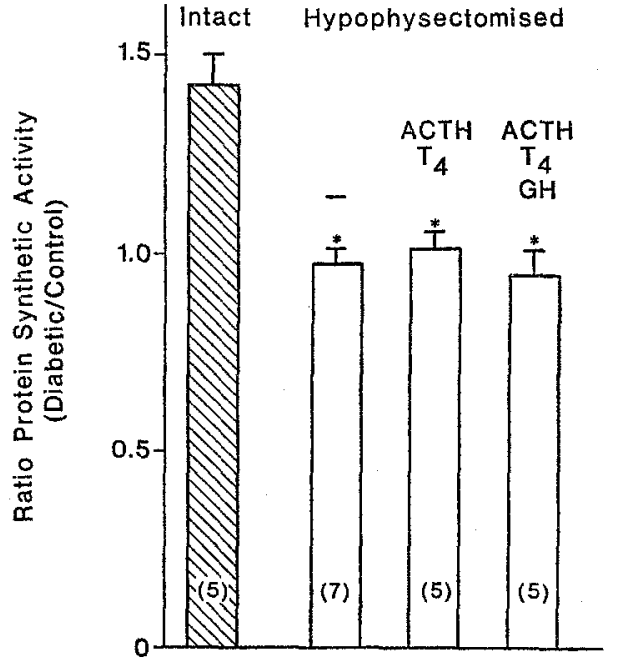

Fig. 2. Protein-synthetic activity of free hepatic ribosomes from livers of control and diabetic Intact, and control and diabetic $\mathrm{Hx}$ (non-hormone, $\mathrm{ACTH} / \mathrm{T}_{4}$ and $\mathrm{ACTH} / \mathrm{T}_{4} / \mathrm{GH}$ treated) rats. Results are shown as mean ratio of diabetic/ control paired samples, and a ratio of $I$ would indicate that the protein-synthetic activity of diabetic and control rats were equal. The four histograms (mean $\pm S E$ ) are obtained from $30 \mathrm{~min}$ incubations in which protein synthesis was directed by endogenous mRNA. The numbers in parenthesis indicate the number of pairs in each experimental group. The $\mathrm{p}$ statistic, $<0.01$ denoted by *, refers to the comparisons between the Intact and each Hx group

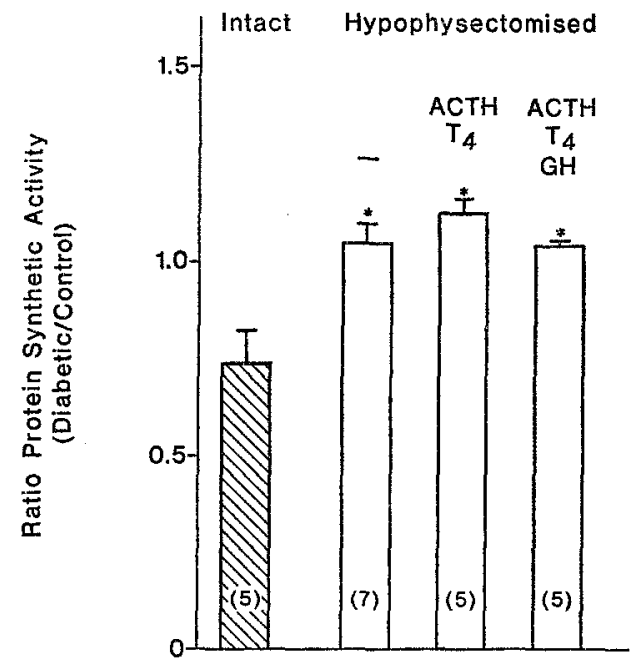

Fig. 3. Protein-synthetic activity of bound hepatic ribosomes from livers of control and diabetic Intact, and control and diabetic $\mathrm{Hx}$ (non-hormone, $\mathrm{ACTH} / \mathrm{T}_{4}$ and $\mathrm{ACTH} / \mathrm{T}_{4} / \mathrm{GH}$ treated) rats. Results are shown as mean ratio of diabetic/ control paired samples, and details of the experimental proceedures and statistical analysis are similar to Fig. 2

streptozotocin to normal rats leads to certain changes in in vitro hepatic protein synthesis, e.g., protein synthetic activity per $\mathrm{mg}$ of ribosomal RNA is increased for free ribosomes and decreased for bound ribosomes,

Table 2. Effect of diabetes on protein synthetic activity of hepatic bound and free ribosomes in Intact and $\mathrm{Hx}$ (non-hormone, $A C T H / T_{4}$ and $A C T H / T_{4} / G H$ treated) rats

\begin{tabular}{|c|c|c|c|c|}
\hline \multirow[t]{3}{*}{ Group } & \multicolumn{4}{|c|}{ Protein Synthetic Activity } \\
\hline & \multicolumn{2}{|c|}{$\begin{array}{l}{\left[10^{3} \times \mathrm{cpm} / \mathrm{mg} \text { ribosomal } \mathrm{RNA}\right]} \\
\text { Free Ribosomes }\end{array}$} & \multicolumn{2}{|c|}{ Bound Ribosomes } \\
\hline & Control & Diabetic & Control & Diabetic \\
\hline Intact & $56.6 \pm 2.7$ & $94.6 \pm 9.3$ & $71.5 \pm 13.3$ & $55.8 \pm 15.2$ \\
\hline \multicolumn{5}{|c|}{ Hypophysectomised } \\
\hline - & $21.3 \pm 2.5$ & $22.5 \pm 3.5$ & $15.2 \pm 2.9$ & $16.6 \pm 3.3$ \\
\hline $\mathrm{ACTH} / \mathrm{T}_{4}$ & $44.3 \pm 3.8$ & $47.9 \pm 6.0$ & $62.6 \pm 5.6$ & $72.0 \pm 5.1$ \\
\hline $\mathrm{ACTH} / \mathrm{T}_{4} / \mathrm{GH}$ & $42.7 \pm 2.8$ & $41.8 \pm 6.3$ & $61.1 \pm 4.7$ & $63.5 \pm 4.4$ \\
\hline
\end{tabular}

synthesis by bound hepatic polyribosomes (Fig. 3). However, protein synthesis by bound polyribosomes from $\mathrm{Hx}$ rats was not decreased, and even with full hormone replacement of $\mathrm{ACTH} / \mathrm{T}_{4} / \mathrm{GH}$, the ratios remained significantly higher than the Intact group (Fig. 3).

\section{Discussion}

The data presented in this paper clearly demonstrate that the previously $[1-3]$ described responses of free and bound hepatic ribosomes to acute experimental diabetes cannot be due to insulin deficiency per se. Thus, the administration of $100 \mathrm{mg}$ per $\mathrm{kg}$ of as compared to non-diabetic controls. On the other hand, administration of an identical amount of streptozotocin to $\mathrm{Hx}$ rats does not lead to any change in hepatic protein synthesis as compared to non-diabetic controls. Furthermore, the administration of ACTH, $\mathrm{T}_{4}$ and $\mathrm{GH}$ in replacement doses to $\mathrm{Hx}$ rats does not restore the pattern of hepatic protein synthesis to that seen in acutely insulin-deficient rats with intact pituitary function. Therefore, it appears that it is the response of the pituitary gland to the state of acute insulin-deficiency which is necessary for the development of the described changes [3] in protein synthetic activity of free and membrane-bound hepatic polyribosomes. 
These studies do not, however, indicate the mechanism by which the pituitary effect is mediated. The severity of the diabetes is clearly less in $\mathrm{Hx}$ diabetes rats and, although hormone replacement leads to increasing hyperglycaemia and weight loss, the severity of the diabetic state of hormone-treated $\mathrm{Hx}$ rats also remains less than that of Intact diabetic rats. Since hypophysectomy is known to ameliorate diabetes and its metabolic sequelae $[19-22]$, it is possible that the observed changes in hepatic protein synthesis of Intact diabetic rats are a function of the severity of the diabetes.

Alternatively, it is possible that the changes in hepatic protein synthesis that occur in the Intact diabetic rat result from the direct effects on the liver of the secretion of excessive amounts of hormone from the pituitary or its target glands, secondary to the diabetic state [23]. Obviously, such increases in pituitary hormone secretion would not take place in $\mathrm{Hx}$ rats with diabetes which were receiving only fixed physiological replacement doses of hormone $[6,7,8$, 9]. However, this possibility seems less likely in view of the fact that the administration of extremely large amounts of $\mathrm{T}_{4}, \mathrm{GH}$ and cortisone have not been shown $[21,25,26]$ to produce the specific changes in hepatic protein synthesis by free or bound ribosomes that are seen in the acutely insulin deficient state [3].

In conclusion, these results highlight the difficulty in assigning causality in a complex syndrome of hormonal deficiency. The previous studies [3] indicated that the specific changes observed in protein synthetic activity of bound and free ribosomes isolated from livers of rats with experimental diabetes, were independent of the experimental form of diabetes, were reversed by the administration of insulin, and were prevented by the concomitant administration of insulin. These data suggested, therefore, that the findings were specific for insulin-deficiency [3]. The results of the current study indicate that the observed changes in hepatic protein synthesis are probably secondary to the metabolic sequelae of insulin lack and that the pituitary response to insulin lack is likely to be important in the pathogenesis of these changes. Further studies will be necessary to more precisely define the role of the pituitary hormones in the control of the response in hepatic protein synthesis to acute insulin deficiency.

\section{References}

1. Tragl, K. H., Reaven, G. M.: Effect of experimental diabetes mellitus on protein synthesis by liver ribosomes. Diabetes 20, 27-32 (1971)

2. Reaven, E. P., Peterson, D. T., Reaven, G. M.: The effect of experimental diabetes mellitus and insulin replacement on hepatic ultrastructure and protein synthesis. J. clin. Invest. 52, 248-262 (1973)

3. Peterson, D. T., Alford, F. P., Reaven, E. P., Ueyama, I., Reaven, G. M.: Characteristics of membrane-bound and free hepatic ribosomes from insulin-deficient rats. I. Acute experimental diabetes mellitus. J. clin. Invest. 52, $3201-3211$ (1973)

4. Houssay, B. A., Biasotti, A.: The hypophysis, carbohydrate metabolism and diabetes. Endocrinology 15, 511-519 (1931)

5. Weber, G.: Study and evaluation of regulation of enzyme activity and synthesis in mammalian liver. In: Advances enzyme regulation (ed. G. Weber), p. 1. New York: Macmillan Company, 1963

6. Thorngren, K. G., Hansson, L. I., Menander-Sellman, K., Stenström, A.: Effect of dose and administration period of growth hormone on longitudinal bone growth in the hypophysectomized rat. Acta endocr. 74, 1-23 (1973)

7. Thorngren, K. G., Hansson, L. I.: Effect of thyroxine and growth hormone on longitudinal bone growth in the hypophysectomized rat. Acta endocr. 74, 24-40 (1973)

8. Sayers, M. A., Sayers, G., Woodbory, I. A.: The assay of adrenocorticotrophic hormone by the adrenal ascorbic acid-depletion method. Endocrinology 42, 379-393 (1948)

9. Schatz, H., Katsilambros, N., Hinz, M., Voigt, K. H., Nierle, C., Pfeiffer, E. P.: Hypophysis and function of pancreatic islets. II. The effect of substitution with growth hormone and corticotrophin on insulin secretion and biosynthesis of proinsulin and insulin in isolated pancreatic islets of hypophysectomized rats. Diabetologia 9, 140144 (1973)

10. Blobel, G., Potter, V. R.: Studies on free and membranebound ribosomes in rat liver. $I$. Distribution as related to total cellular RNA. J. molec. Biol. 26, 279-292 (1967)

11. Blobel, G., Potter, V. R.: Studies on free and membranebound ribosomes in rat liver. II. Interaction of ribosomes and membranes. J. molec. Biol. 27, 293-301 (1967)

12. Blobel, G., Potter, V. R.: Relation of ribonuclease and ribonuclease inhibitor to the isolation of polysomes from rat liver. Proc. nat. Acad. Sci. (Wash.) 55, 1283-1288 (1966)

13. Richardson, A., McGown, E., Henderson, L. M., Swan, P. B.: In vitro amino acid incorporation by the post mitochondrial supernatant of rat liver. Biochim. biophys. Acta (Amst.) 254, 468-477 (1971)

14. Hoagland, M. B., Stephenson, M. L., Scott, J. F., Hecht, L. C., Zamecnik, P. C.: A soluble ribonucleic acid intermediate in protein synthesis. J. biol. Chem. 231, 241-257 (1958)

15. Mazzaferri, E. L., Stillman, G., Lanese, R. R., Keller, M. P.: Use of test strips with color meter to measure bloodglucose. Lancet 1970 I, 331-333

16. Fleck, A., Munro, H. N.: The precision of ultraviolet absorption measurements in the Schmidt-Thannhauser procedure for nucleic acid estimation. Biochim. biophys. Acta (Amst.) 55, 571-583 (1962)

17. Lowry, O. H., Rosebrough, N. J., Farr, A. L., Randall, R. J.: Protein measurement with the eolin phenol reagent. J. biol. Chem. 193, 265-272 (1951)

18. Armitage, P.: Statistical methods. In: Medical research. p. 99. Oxford-Edinburgh: Blackwell Scientific Publications 1971

19. Chernick, S. S., Clark, C. M., Gardiner, R. J., Scow, R. O.: Role of lipolytic and glucocorticoid hormones in the 
development of diabetic ketosis. Diabetes 21, 946-954 (1972)

20. Scow, R. O., Chernick, S. S., Guarco, B. A.: Ketogenic action of pituitary and adrenal hormones in pancreatectomised rats. Diabetes 8, 132-141 (1959)

21. Scow, R. O., Wagner, E.M., Cardeza, A.: Effect of hypophysectomy in the insulin requirement and response to fasting of "totally" pancreatectomised rats. Endocrinology 61, 380-391 (1957)

22. Scow, R. O.: Effect of growth hormone on growth in hypophysectomised-pancreatectomised rats. Endocrinology 61, 582-586 (1957)

23. L'age, M., Fechner, W., Langholz, J., Salzmann, H.: Relationships between plasma corticosterone and the development of ketoacidosis in alloxan diabetic rat. Diabetologia 10, 131 - 134 (1974)

24. Tata, J. R., Williams-Ashmann, H. G.: Effects of growth hormone and tri-iodothyronine on amino acid incorporation by microsomal subfractions from rat liver. Europ. J. Biochem. 2, 366-374 (1967)

25. Korner, A.: The effect of growth hormone on protein synthesis in the absence of peptide chain initiation. Biochim. biophys. Acta (Amst.) 174, 351-358 (1969)

26. Leon, H. A., Arrhenius, E., Hultin, T.: Effects of glucocorticoid administration on the incorporation of labelled amino acids into protein by cell-free rat-liver systems. Biochim. biophys. Acta (Amst.) 63, 423-433 (1962)
Dr. F. P. Alford c/o Dept. of Medicine
Univ. of Melbourne
St. Vincents Hosp.
Victoria Parade
Fitzroy, Victoria
Australia 